\title{
Ocena książki Chirurgia zatok przynosowych - dostępy zewnątrznosowe pod redakcją Antoniego Krzeskiego, Wydawnictwo Medycyna Praktyczna, Kraków 2011
}

\author{
The review of book Paranasal sinuses surgery - extranasal accesses edited by Antoni Krzeski, \\ Publisher Medycyna Praktyczna, Krakow 2011
}

Paweł Stręk

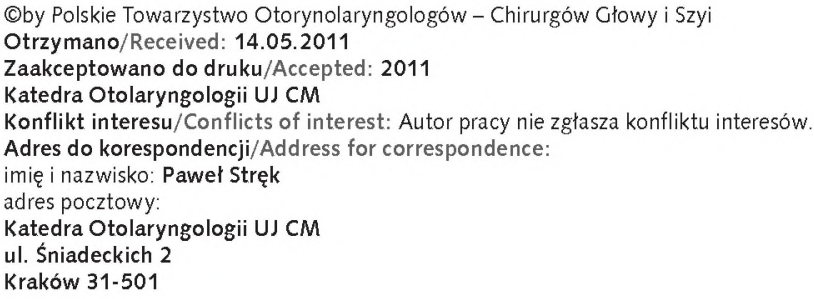

Omawiany podręcznik ukazał się pod redakcją pro fesora Antoniego Krzeskiego w 2011 r. Jest kolejna monografią wydaną pod redakcja profesora Krzeskiego z zakresu rynologii i rynochirurgii.

Wśród Autorów odnajdujemy nazwiska wielu kra jowych rynochirurgów o ogromnym došwiadezeniu klinicznym, profesorów: Bienia, Golusińskiego, Janczewskiego, Jurkiewicza, Misiołka, Osuch-Wójcikiewicz i Stankiewicza oraz doktora Swierczyńskiego.

Monografia składa się z 7 rozdziałów, obejmuje 114 stron, jest bogato ilustrowana rycinami, tabelami i schematami.

We wprowadzeniu profesor Krzeski, przedstawia jąc droge powstawania tego podręcznika, akcentuje koniecznoșć znajomości tej części rynochirurgii w dobie coraz powszechniejszego stosowania technik endoskopowych. Endoskopowa chirurgia nosa i zatok przynosowych, rozwijając się niezmiernie dynamicznie i ekspansywnie, niestety w niektörych sytuacjach okazuje się nieskuteczna. Fascynacja zastosowaniem endoskopu i mikroskopu operacyjnego, jakkolwiek w pełni wytłumaczalna, rodzi niestety niebezpieczeństwo, $i \dot{z}$ operacje $z$ dostępów zewnątrznosowych, coraz rzadziej wykonywane, mogą dla najmłodszych adeptów rynochirurgii stać się zupełnie nieznane. A przecież, jak zauważył profesor Krzeski: „Wszak zawsze istnieje podczas każdej operacji zagrożenie, w wyniku którego należy odstąpić od wykonywania mikrochirurgii wewnątrznosowej i dokończyć postępowanie operacyjne metodą klasyczną. I ta umiejętność czyni z chirurga mistrza”. $Z$ kolei zrozumienie konieczności stworzenia takiego podręcznika czyni z jego Autorôw twórców dzieła nie tylko ogromnie potrzebnego, ale także unikatowego.

Kolejne rozdziały poświęcone są planowaniu cięć chirurgicznych zarówno w obrębie skóry twarzy, jak i błony śluzowej jamy ustnej, oraz technik chirurgicznych umożliwiających dostęp do wszystkich grup zatok przynosowych. W tworzeniu poszczególnych rozdziałôw Autorzy szczegółowo wymieniaja powikłania, ktôrych możliwość wystąpienia towarzyszy każdemu z opisy wanych etapów zabiegów operacyjnych. Te cenne uwagi pozwola podczas planowania zabiegu operacyjnego, a następnie podczas jego realizacji, uniknacc stresujących dla chirurga, a czasami tragicznych w skutkach dla chorego, zdarzeń.

Przedostatni rozdział dotyczący resekcji szczęki, zawierający kompendium wiedzy niezbędnej dla skutecznego leczenia operacyjnego chorych z nowotworami masywu szczękowo-sitowego, został wzbogacony przez Autorów o tabele systematyzujące objawy nowotworów tego regionu, jak i stopień zaawansowania miejscowego raka, ocenę regionalnych węzłów chłonnych oraz przerzutów odległych, wg TNM.

Ostatni rozdział poświecony jest dostępom do masywu szczękowo-sitowego. W tym, jak i w poprzednio omawianym, zwraca uwage czytelny i przejrzysty układ tekstu, w którym zaakcentowano wspomniane poprzednio niebezpieczeństwo wystąpienia potencjalnych powikłań, jak i wskazania do zastosowania opisywanych technik operacyjnych. Użyteczność prezentowanych wiadomości dla praktykujacych chirurgów zwiększa obecność podrozdziałów przedstawiających praktyczne uwagi Autorów dotyczące opisywanych zagadnieñ oraz zalecenia związane $z$ prawidłowym postępowaniem pooperacyjnym.

Jak przystało na podręcznik technik chirurgicznych, wszystkie rozdziały sa bogato ilustrowane czytelnymi i zrozumiałymi rycinami i schematami przedstawiajacymi kolejne etapy prezentowanych procedur operacyjnych. Omawiany podręcznik jest pierwszą tak obszerną publikacją na temat dostępów 
zewnątrznosowych stosowanych w chirurgii zatok przynosowych.

Jestem pewien, że przedstawiona monografia będzie służyła nie tylko otorynolaryngologom, a w szczególności rynochirurgom, ale także wszystkim lekarzom zajmującym się chirurgią głowy i szyi.

Poza niewątpliwymi walorami merytorycznymi książka jest przyjemna w odbiorze, dzięki właściwie dobranemu językowi, rozpoznawalnemu już w poprzednich publikacjach redagowanych przez profesora Krzeskiego.

W imieniu czytelników składam gorące podziękowanie i wyrazy uznania Autorom i Redaktorowi niniejszej monografii za trud i czas poświęcony opracowaniu tego bardzo wartościowego dzieła. 